\title{
Front Matter: Volume 8893
}

, "Front Matter: Volume 8893," Proc. SPIE 8893, Earth Resources and Environmental Remote Sensing/GIS Applications IV, 889301 (11 November 2013); doi: $10.1117 / 12.2051075$

SPIE. Event: SPIE Remote Sensing, 2013, Dresden, Germany 


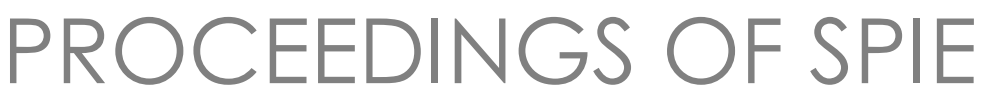

\title{
Earth Resources and Environmental Remote Sensing/GIS Applications IV
}

\author{
Ulrich Michel \\ Daniel L. Civco \\ Karsten Schulz \\ Manfred Ehlers \\ Konstantinos G. Nikolakopoulos \\ Editors
}

\section{3-25 September 2013 \\ Dresden, Germany}

Sponsored by

SPIE

Cooperating Organisations

European Association of Remote Sensing Companies (Belgium)

Remote Sensing and Photogrammetry Society (United Kingdom)

Deutsche Gesellschaft für Photogrammetrie, Fernerkundung und Geoinformation e.V.

(Germany)

European Optical Society

Published by

SPIE 
The papers included in this volume were part of the technical conference cited on the cover and title page. Papers were selected and subject to review by the editors and conference program committee. Some conference presentations may not be available for publication. The papers published in these proceedings reflect the work and thoughts of the authors and are published herein as submitted. The publisher is not responsible for the validity of the information or for any outcomes resulting from reliance thereon.

Please use the following format to cite material from this book:

Author(s), "Title of Paper," in Earth Resources and Environmental Remote Sensing/GIS Applications IV, edited by Ulrich Michel, Daniel L. Civco, Karsten Schulz, Manfred Ehlers, Konstantinos G. Nikolakopoulos, Proceedings of SPIE Vol. 8893 (SPIE, Bellingham, WA, 2013) Article CID Number.

ISSN: 0277-786X

ISBN: 9780819497635

Published by

SPIE

P.O. Box 10, Bellingham, Washington 98227-0010 USA

Telephone +1 3606763290 (Pacific Time) · Fax +1 3606471445

SPIE.org

Copyright (C) 2013, Society of Photo-Optical Instrumentation Engineers.

Copying of material in this book for internal or personal use, or for the internal or personal use of specific clients, beyond the fair use provisions granted by the U.S. Copyright Law is authorized by SPIE subject to payment of copying fees. The Transactional Reporting Service base fee for this volume is $\$ 18.00$ per article (or portion thereof), which should be paid directly to the Copyright Clearance Center (CCC), 222 Rosewood Drive, Danvers, MA 01923. Payment may also be made electronically through CCC Online at copyright.com. Other copying for republication, resale, advertising or promotion, or any form of systematic or multiple reproduction of any material in this book is prohibited except with permission in writing from the publisher. The CCC fee code is 0277-786X/13/\$18.00.

Printed in the United States of America.

Publication of record for individual papers is online in the SPIE Digital Library.

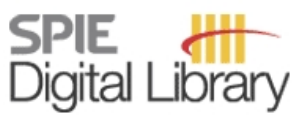

SPIEDigitalLibrary.org

Paper Numbering: Proceedings of SPIE follow an e-First publication model, with papers published first online and then in print and on CD-ROM. Papers are published as they are submitted and meet publication criteria. A unique, consistent, permanent citation identifier (CID) number is assigned to each article at the time of the first publication. Utilization of CIDs allows articles to be fully citable as soon as they are published online, and connects the same identifier to all online, print, and electronic versions of the publication. SPIE uses a six-digit CID article numbering system in which:

- The first four digits correspond to the SPIE volume number.

- The last two digits indicate publication order within the volume using a Base 36 numbering

system employing both numerals and letters. These two-number sets start with 00, 01, 02, 03, 04, $05,06,07,08,09,0 A, 0 B \ldots$. 0Z, followed by 10-1Z, 20-2Z, etc.

The CID Number appears on each page of the manuscript. The complete citation is used on the first page, and an abbreviated version on subsequent pages. Numbers in the index correspond to the last two digits of the six-digit CID Number. 


\section{Contents}

ix Conference Committee

xi Introduction

\section{SESSION 1 INFRASTRUCTURES AND URBAN AREAS I}

889302 Quantification of changes in oil sands mining infrastructure land based on RapidEye and SPOT5 [8893-1]

Y. Zhang, N. Lantz, B. Guindon, Natural Resources Canada (Canada); T. Shipman,

D. Chao, Government of Alberta (Canada); D. Raymond, Natural Resources Canada (Canada)

889303 Derivation of urban objects and their attributes for large-scale urban areas based on very high resolution UltraCam true orthophotos and nDSM: a case study Berlin, Germany [8893-2]

A. M. Poznanska, Deutsches Zentrum für Luft- und Raumfahrt e.V. (Germany); S. Bayer, Freie Univ. Berlin (Germany); T. Bucher, Deutsches Zentrum für Luft- und Raumfahrt e.V. (Germany)

889304 Monitoring the effects of land use/landcover changes on urban heat island [8893-4] O. K. Gee, Univ. Teknologi Malaysia (Malaysia); M. L. R. Sarker, Univ. Teknologi Malaysia (Malaysia) and Univ. of Rajshahi (Bangladesh)

\section{SESSION 2 INFRASTRUCTURES AND URBAN AREAS II}

889305 Generalized interpretation scheme for arbitrary HR InSAR image pairs [8893-5]

M. Boldt, Fraunhofer-Institut für Optronik, Systemtechnik und Bildauswertung (Germany); A. Thiele, Fraunhofer-Institut für Optronik, Systemtechnik und Bildauswertung (Germany) and Karlsruhe Institute of Technology (Germany); K. Schulz, Fraunhofer-Institut für Optronik, Systemtechnik und Bildauswertung (Germany)

889307 Simulation of close range remote sensing of subsurface features using GPR for urban utility information system development [8893-7]

A. V. Hebsur, N. Muniappan, E. P. Rao, G. Venkatachalam, Indian Institute of Technology Bombay (India)

\section{SESSION 3 GIS EDUCATION}

889308 GIS4schools: custom-made GIS-applications for educational use [8893-9]

T. Demharter, U. Michel, Pädagogische Hochschule Heidelberg (Germany) 
8893 OB Remote sensing of vegetation in a tropical mountain ecosystem: individual tree-crown detection [8893-12]

B. Silva, J. Bendix, Philipps-Univ. Marburg (Germany)

8893 OC Identification of urban tree crown in a tropical environment using WorldView-2 data: problems and perspectives [8893-13]

M. F. Gomes, Univ. Federal de Minas Gerais (Brazil); P. Maillard, Univ. Federal de Minas Gerais (Brazil) and Lab. d'Études en Géophysique et Océanographie Spatiales (France)

\section{SESSION 5 REMOTE SENSING FOR ARCHAEOLOGY, CULTURAL AND NATURAL HERITAGE}

8893 OD Prospects and limitations of vegetation indices in archeological research: the Neolithic Thessaly case study [8893-14]

A. Agapiou, D. D. Alexakis, M. Stavrou, Cyprus Univ. of Technology (Cyprus); A. Sarris, Foundation for Research and Technology-Hellas (Greece); K. Themistocleous,

D. G. Hadjimitsis, Cyprus Univ. of Technology (Cyprus)

8893 OE Fluorescence lidar measurements at the archaeological site House of Augustus at Palatino, Rome [8893-15]

V. Raimondi, Istituto di Fisica Applicata Nello Carrara, CNR (Italy); C. Alisi, ENEA (Italy);

K. Barup, Lund Univ. (Sweden); M. P. Bracciale, A. Broggi, Univ. degli Studi di Roma La Sapienza (Italy); C. Conti, Soprintendenza Speciale ai Beni Archeologici di Roma (Italy); J. Hällström, Lund Univ. (Sweden); D. Lognoli, L. Palombi, Istituto di Fisica Applicata Nello Carrara, CNR (Italy); M. L. Santarelli, Univ. degli Studi di Roma La Sapienza (Italy);

A. R. Sprocati, ENEA (Italy)

\section{SESSION 6 ENVIRONMENTAL MONITORING I}

8893 Ol Determining suitable image resolutions for accurate supervised crop classification using remote sensing data [8893-21]

F. Löw, Julius-Maximilians-Univ. Würzburg (Germany); G. Duveiller, European Commission Joint Research Ctr. (Italy)

$88930 \mathrm{~J}$ Retrieval of fire radiative power and biomass combustion using the Korean geostationary meteorological satellite [8893-22]

D. S. Kim, Y. W. Lee, Pukyong National Univ. (Korea, Republic of)

\section{SESSION 7 ENVIRONMENTAL MONITORING II}

$8893 \mathrm{OL} \quad$ Remote sensing methods to monitor habitats potentially threatened by climate change [8893-24]

M. Förster, T. Schmidt, Technische Univ. Berlin (Germany); N. Spindler, K. Renner, EURAC research (Italy); I. Wagner-Lücker, Univ. Wien (Austria); M. Zebisch, EURAC research (Italy); M. Neubert, Leibniz Institute of Ecological Urban and Regional Development (Germany) 
8893 OM Assessing error sources for Landsat time series analysis for tropical test sites in Viet Nam and Ethiopia [8893-25]

M. Schultz, J. Verbesselt, M. Herold, V. Avitabile, Wageningen Univ. (Netherlands)

$8893 \mathrm{ON}$ The use of decision trees in the classification of beach forms/patterns on IKONOS-2 data [8893-26]

A. C. Teodoro, D. Ferreira, H. Gonçalves, Univ. do Porto (Portugal)

889300 Remote sensing and spatial analysis based study for detecting deforestation and the associated drivers [8893-27]

M. M. El-Abbas, E. Csaplovics, T. H. Deafalla, Technische Univ. Dresden (Germany)

\section{SESSION 8 HAZARD MITIGATION: GEOLOGIC APPLICATIONS}

8893 OP Remote sensing data and GIS for hydrological studies [8893-28]

E. Kouzeli, N. Lambrakis, K. G. Nikolakopoulos, Univ. of Patras (Greece)

$8893 \mathrm{OQ}$ Landslide hazard assessment along a mountain highway in the Indian Himalayan Region (IHR) using remote sensing and computational models [8893-29]

A. P. Krishna, S. Kumar, Birla Institute of Technology (India)

\section{SESSION 9 PROCESSING METHODOLOGIES II}

8893 OT Evaluation of commercial available fusion algorithms for Geoeye data [8893-32]

A. D. Vaiopoulos, Univ. of Athens (Greece); K. G. Nikolakopoulos, Univ. of Patras (Greece)

8893 OU Forest structure estimates with GEOBIA and multi-scale optical sensors [8893-33]

M. M. El Abbas, Technische Univ. Dresden (Germany) and Univ. Khartoum (Sudan);

E. Csaplovics, Technische Univ. Dresden (Germany); T. H. H. Deafalla, Technische Univ. Dresden (Germany) and Univ. Khartoum (Sudan)

8893 OV Ground-based multispectral measurements for airborne data verification in non-operating open pit mine "Kremikovtsi" [8893-34]

D. Borisova, H. Nikolov, D. Petkov, Space Research and Technology Institute (Bulgaria)

SESSION 10 ENVIRONMENTAL MONITORING III

8893 OX Development of a fire detection algorithm for the COMS (Communication Ocean and Meteorological Satellite) [8893-36]

G. Kim, D. S. Kim, Y.-W. Lee, Pukyong National Univ. (Korea, Republic of)

8893 OY The impact of the day of observation of image composites on adequate time series generation [8893-37]

R. R. Colditz, R. A. Ressl, CONABIO (Mexico) 
$88930 Z$ Applying the Manning equation to determine the critical distance in non-point source pollution using remotely sensed data and cartographic modelling [8893-38]

L. M. de Oliveira, Ctr. Federal de Educação Tecnológica de Minas Gerais (Brazil) and Univ. Federal de Minas Gerais (Brazil); N. A. P. Santos, Instituto Mineiro de Gestâo das Águas (Brazil); P. Maillard, Univ. Federal de Minas Gerais (Brazil)

\section{SESSION 11 ENVIRONMENTAL MONITORING IV}

889310 Identification of bamboo patches in the lower Gangetic plains using very high resolution WorldView 2 imagery [8893-39]

A. Ghosh, P. K. Joshi, TERI Univ. (India)

889311 Use of empirically based land use dynamics model with climate and socio-economic parameters in a rain-fed agricultural area [8893-40]

V. R., M. R., Anna Univ. Chennai (India)

889312 Assessment of vegetation change and its causes in the West Liaohe River Basin of China using SPOT-VGT image [8893-41]

F. Huang, H. Zhang, P. Wang, Northeast Normal Univ. (China)

889313 Estimate ecological indicators of karst rocky desertification by spectral unmixing algorithm [8893-42]

$X$. Zhang, Institute of Remote Sensing and Digital Earth (China); T. Shuai, Institute of Remote Sensing and Digital Earth (China) and Univ. of the Chinese Academy of Sciences (China);

B. Yang Institute of Remote Sensing and Digital Earth (China); Z. Zhuang, Institute of Remote Sensing and Digital Earth (China) and Univ. of Chinese Academy of Sciences (China)

889314 Snow cover and land surface temperature assessment of Gangotri basin in the Indian Himalayan Region (IHR) using MODIS satellite data for climate change inferences [8893-43] A. P. Krishna, A. Sharma, Birla Institute of Technology (India)

\section{SESSION 12 ENVIRONMENTAL MONITORING IV}

889316 Analysis of principal parameters of forest fires and identification of desertification process in semi-arid land in Algeria [8893-45]

A. Zegrar, Ctr. National des Techniques Spatiales (Algeria)

889317 Identification of impacts on the Egyptian Nile using remote sensing and GIS [8893-46]

A. H. El-Nahry, National Authority for Remote Sensing and Space Sciences (Egypt)

POSTER SESSION

889318 Use of ground penetrating radar for determination of water table depth and subsurface soil characteristics at Kennedy Space Center [8893-48]

G. M. Hengari, InoMedic Health Application (United States) and Florida Institute of Technology (United States); C. R. Hall, T. J. Kozusko, InoMedic Health Application (United

States); C. R. Bostater, Florida Institute of Technology (United States) 
8893 1A Simulation, visualization and GIS analysis based on globe model for PL19-3 oil spill of Bohai Sea [8893-50]

L. Kang, S. Shi, Z. Deng, J. Jin, F. Zhang, National Marine Data and Information Service (China) and The Second Institute of Oceanography, SOA (China); H. Huang, National Marine Data and Information Service (China)

8893 1C Low frequency/high sensitivity triaxial monolithic inertial sensor [8893-53]

F. Acernese, Univ. degli Studi di Salerno (Italy) and INFN (Italy); R. De Rosa, INFN (Italy) and Univ. degli Studi di Napoli Federico II (Italy); G. Giordano, Univ. degli Studi di Salerno (Italy): R. Romano, F. Barone, Univ. degli Studi di Salerno (Italy) and INFN (Italy)

8893 ID Satellite and in-situ monitoring of urban air pollution in relation with children's asthma [8893-54]

M. R. Dida, Univ. of Medicine and Pharmacy of Craiova (Romania); M. A. Zoran, National Institute of Research and Development for Optoelectronics (Romania)

8893 IE Satellite remote sensing image based analysis of effects due to urbanization on climate and health [8893-55]

M. Zoran, National Institute of Research and Development for Optoelectronics (Romania); L. F. Zoran, Univ. Politehnica of Bucharest (Romania); A. Dida, Univ. Transilvania of Brasov (Romania); M. R. Dida, Univ. of Medicine and Pharmacy of Craiova (Romania); A. T. Zoran, Univ. of Medicine and Pharmacy of Bucharest (Romania); O. M. Ionescu, Transilvania Univ. of Brasov (Romania)

8893 IF Measuring pasture degradation on the Qinghai-Tibet Plateau using hyperspectral dissimilarities and indices [8893-56]

H. Meyer, L. W. Lehnert, Philipps-Univ. Marburg (Germany); Y. Wang, Senckenberg Museum of Natural History (Germany); C. Reudenbach, J. Bendix, Philipps-Univ. Marburg (Germany)

$8893 \mathrm{IH}$ Design and construction of Information Systems of Ocean Satellite Monitoring for Air-sea $\mathrm{CO}_{2}$ Flux (IssCO ${ }_{2}$ ) [8893-58]

Q. Zhu, The Second Institute of Oceanography, SOA (China); L. Fang, Zhejiang Univ. (China); Y. Bai, X. He, The Second Institute of Oceanography, SOA (China); X. Sun, Zhejiang Univ. (China); J. Chen, The Second Institute of Oceanography, SOA (China)

889311 Impact of climate and anthropogenic changes on a periurban forest surface albedo derived from MODIS satellite data [8893-59]

M. A. Zoran, R. S. Savastru, D. M. Savastru, National Institute of Research and Development for Optoelectronics (Romania); A. I. Dida, O. M. Ionescu, Transilvania Univ. of Brasov (Romania)

$88931 \mathrm{~K}$ Extraction of urban impervious surface information based on object-oriented technology [8893-61]

A. Liu, X. Zhao, J. Wang, T. He, China Institute of Land Surveying and Planning (China)

8893 IL Attempt of identification of wet areas with ASTER images for archeological studies [8893-62] E. Bertacchini, F. Despini, S. Teggi, A. Capra, Univ. degli Studi di Modena e Reggio Emilia (Italy); M. Dubbini, Univ. of Bologna (Italy) 
$88931 \mathrm{M}$ Wetland mapping and flood extent monitoring using optical and radar remotely sensed data and ancillary topographical data in the Zhalong National Natural Reserve, China [8893-63]

X. Na, S. Zang, Y. Zhang, L. Liu, Harbin Normal Univ. (China)

8893 iN An influence assessment of GSICS correction using sea surface temperature from geostationary satellite: COMS [8893-64]

E.-B. Park, K.-S. Han, J. Cho, C.-S. Lee, I.-H. Kim, K.-J. Pi, J.-H. Ryu, J.-M. Ha, Pukyong National Univ. (Korea, Republic of)

8893 1Q Comparison of different "along the track" high resolution satellite stereo-pair for DSM extraction [8893-67]

K. G. Nikolakopoulos, Univ. of Patras (Greece)

$88931 \mathrm{U}$ Land use and land cover classification, changes and analysis in gum Arabic belt in North Kordofan, Sudan [8893-71]

H. E. Adam, Univ. of Kordofan (Sudan); E. Csaplovics, Technische Univ. Dresden (Germany); M. E. Elhaja, Univ. of Kordofan (Sudan); M. M. El Abbas, Technische Univ. Dresden (Germany)

$88931 \mathrm{~W}$ Object-based change detection in rapid urbanization regions with remotely sensed observations: a case study of Shenzhen, China [8893-3]

L. He, G. Dong, China National Environmental Monitoring Ctr. (China); W.-M. Wang,

L. Yang, H. Liang, Shenzhen Environmental Monitoring Ctr. (China) 


\title{
Conference Committee
}

\author{
Symposium Chair
}

Charles R. Bostater Jr., Florida Institute of Technology (United States)

Symposium Cochair

Ulrich Michel, Pädagogische Hochschule Heidelberg (Germany)

Conference Chairs

Ulrich Michel, Pädagogische Hochschule Heidelberg (Germany)

Daniel L. Civco, University of Connecticut (United States)

Karsten Schulz, Fraunhofer-Institut für Optronik, Systemtechnik und Bildauswertung (Germany)

Conference Cochairs

Manfred Ehlers, Universität Osnabrück (Germany)

Konstantinos G. Nikolakopoulos, University of Patras (Greece)

Conference Program Committee

Thomas Blaschke, Universität Salzburg (Austria)

Tilman U. Bucher, Deutsches Zentrum für Luft- und Raumfahrt e.V. (Germany)

Ni-Bin Chang, University of Central Florida (United States)

Garik Gutman, NASA Headquarters (United States)

Martin Kappas, Georg-August-Universität Göttingen (Germany)

Rosa Lasaponara, Istituto di Metodologie per l'Analisi Ambientale (Italy)

Marguerite M. Madden, The University of Georgia (United States)

Derya Maktav, Istanbul Technical University (Turkey)

Matthias S. Moeller, Beuth Hochschule für Technik Berlin (Germany)

Pablo H. Rosso, Universität Osnabruck (Germany)

Florian Savopol, Natural Resources Canada (Canada)

Jochen Schiewe, HafenCity Universität Hamburg (Germany)

Wenzhong Shi, The Hong Kong Polytechnic University (Hong Kong, China)

Alexander Siegmund, Pädagogische Hochschule Heidelberg (Germany)

Karl Staenz, University of Lethbridge (Canada)

Josef Strobl, Universität Salzburg (Austria)

Kerstin Voss, Rheinische Friedrich-Wilhelms-Universität Bonn (Germany)

Christiane H. Weber, Université of Strasbourg (France) 


\section{Session Chairs}

1 Infrastructures and Urban Areas I

Ulrich Michel, Pädagogische Hochschule Heidelberg (Germany)

Daniel L. Civco, University of Connecticut (United States)

2 Infrastructures and Urban Areas II

Karsten Schulz, Fraunhofer-Institut für Optronik, Systemtechnik und Bildauswertung (Germany)

3 GIS Education

Karsten Schulz, Fraunhofer-Institut für Optronik, Systemtechnik und Bildauswertung (Germany)

4 Processing Methodologies I

Dimitri Bulatov, Fraunhofer-Institut für Optronik, Systemtechnik und Bildauswertung (Germany)

5 Remote Sensing for Archaeology, Cultural and Natural Heritage

Timo Demharter, Pädagogische Hochschule Heidelberg (Germany)

6 Environmental Monitoring I

Sebastian Günthert, Pädagogische Hochschule Heidelberg (Germany)

7 Environmental Monitoring II

Anna Marie Poznanska, Deutsches Zentrum für Luft- und Raumfahrt e.V. (Germany)

8 Hazard Mitigation: Geologic Applications

Konstantinos G. Nikolakopoulos, University of Patras (Greece)

9 Processing Methodologies II

Konstantinos G. Nikolakopoulos, University of Patras (Greece)

10 Environmental Monitoring III

René Colditz, La Comisión Nacional para el Conocimiento y Uso de la Biodiversidad (Mexico)

11 Environmental Monitoring

Shahid Habib, NASA Goddard Space Flight Center (United States)

Daniel L. Civco, University of Connecticut (United States)

12 Environmental Monitoring IV

Denitsa Borisova, Space Research and Technology Institute (Bulgaria) 


\section{Introduction}

These proceedings contain 46 papers presented at the SPIE Conference 8893, Earth Resources and Environmental Remote Sensing/GIS Applications, formerly known as 'Remote Sensing for Environmental Monitoring, GIS Applications, and Geology.' The conference took place 23-25 September 2013 in Dresden, Germany. It was the thirteenth conference with this topic after its inauguration in Toulouse, France, in 2001.

The conference sessions with presented papers and interactive posters were grouped into the following themes: Infrastructures and Urban Areas, GIS Education, Processing Methodologies, Remote Sensing for Archaeology, Cultural and Natural Heritage, Environmental Monitoring and Hazard Mitigation Geologic Applications. Lively discussions often continued into the coffee breaks. Although the session topics seemed rather diverse, there was a common thread to many papers, i.e., application of remotely sensed data for the protection of our environment, the integration with geographic information Systems (GIS) and change detection. There was strong support from the audience to continue these themes for future conferences.

The paper submission and review process were again perfectly organized by the SPIE staff. We like to thank the SPIE staff on-site for their responsiveness and support. We are also grateful to our program committee for their help in the reviewing and session compilation process.

Ulrich Michel

Daniel L. Civco

Karsten Schulz

Manfred Ehlers

Konstantinos G. Nikolakopoulos 
Proc. of SPIE Vol. $8893889301-12$

Downloaded From: https://www.spiedigitallibrary.org/conference-proceedings-of-spie on 26 Apr 2023 Terms of Use: https://www.spiedigitallibrary.org/terms-of-use 